\title{
Kualitas Makroskopis Semen Ayam Kampung Yang Diberi Ekstrak Kulit Buah Naga
}

\author{
Dhian Ramadhanty ${ }^{1}$, Angga Nugraha ${ }^{1}$, Nurul Purnomo ${ }^{1}$, Andi Fausiah ${ }^{2}$ \\ ${ }^{1}$ Universitas Muhammadiyah Sidenreng Rappang \\ ${ }^{2}$ Universitas Al Asyariah Mandar \\ *Email: dhianquinsa77@gmail.com
}

\begin{abstract}
Abstrak
Tujuan penelitian ini untuk mengetahui pengaruh ekstrak kulit buah naga terhadap kualitas semen ayam kampung. Penelitian ini menggunakan Rancangan Acak Lengkap yang terdiri dari 4 perlakuan dan 3 ulangan. 12 ekor ayam Kampung jantan dibagi secara acak dalam 4 kelompok perlakuan. Sebelum perlakuan, seluruh ayam diadaptasikan selama 10 hari dan hanya diberi pakan komersil dan air minum. Perlakuan diberikan secara oral selama 8 minggu dan terdiri dari $\mathrm{P} 0=$ Kontrol, $\mathrm{P} 1=$ Ekstrak kulit buah naga $1 \mathrm{ml}, \mathrm{P} 2=\mathrm{Ekstrak}$ kulit buah naga $3 \mathrm{ml}$, dan $\mathrm{P} 3=$ Ekstrak kulit buah naga $5 \mathrm{ml}$ kemudian dilakukan penampungan semen dengan metode pengurutan. Sperma yang telah ditampung kemudian diuji kualitasnya di Laboratorium. Parameter yang diukur yaitu kualitas semen secara makroskopis meliputi warna, bau, konsistensi, volume, dan $\mathrm{pH}$ semen. Hasil penelitian menunjukkan bahwa pemberian ekstrak kulit buah naga tidak memberikan pengaruh yang nyata terhadap warna, bau, konsistensi, dan $\mathrm{pH}$ semen tetapi memberikan pengaruh pada volume semen yaitu volume semen ayam yang diberi perlakuan lebih tinggi dibandingkan dengan ayam yang tidak diberi perlakuan. Secara keseluruhan semen yang diperoleh memiliki kualitas yang baik dan normal baik yang diberi perlakuan maupun yang tidak diberi perlakuan.
\end{abstract}

Kata Kunci : Ayam Kampung, Kulit Buah Naga, Makroskopis, Semen, Spermatozoa

\section{Pendahuluan}

Usaha peternakan ayam kampung merupakan jenis usaha pemeliharaan ternak yang unggul dan menjanjikan dalam beberapa tahun terakhir. Permintaan daging ayam Kampung semakin meningkat dari tahun ke tahun seiring dengan pertambahan penduduk dan pendapatan masyarakat. Persepsi bahwa daging ayam kampung lebih sehat membuat konsumsinya terus meningkat. Harga jual ayam kampung juga lebih mahal dibandingkan dengan ayam broiler karena perbedaan kualitas dagingnya. Daging ayam kampung mempunyai cita rasa dan tekstur yang khas serta memiliki nilai nutrisi yang lebih baik sehingga banyak disukai masyarakat Indonesia.

Ayam Kampung memiliki beberapa keunggulan yaitu mudah beradaptasi dengan lingkungan sekitar, lebih tahan terhadap penyakit dan cuaca, tidak mudah stress, sistem pemeliharaannya mudah dan tidak memerlukan lahan yang luas dibandingkan dengan ayam Broiler. Namun disamping memiliki keunggulan, ayam kampung juga memiliki beberapa kelemahan seperti pertumbuhan yang lambat, produksi rendah, masih mempunyai sifat mengeram, lambat dewasa kelamin, dan rendahnya mutu genetik (Danang dkk, 2012). Ketersediaan bibit ayam kampung yang baik serta tingkat produktivitas yg rendah juga menjadi kelemahan dalam pemeliharaan ayam kampung. Rendahnya produktivitas ayam kampung disebabkan oleh tingginya variasi genetik akibat sistem perkawinan bebas secara alami yang telah berjalan lama (Yaman, 2013).

Untuk mengatasi rendahnya mutu genetik dan memperbaiki produktivitas ayam kampung serta untuk menyediakan bibit ayam kampung yang baik dalam jumlah banyak dapat dilakukan dengan menggunakan aplikasi bioteknologi repropuksi berupa Inseminasi Buatan dengan semen yang berkualitas baik. Keberhasilan program IB ditentukan oleh 4 faktor utama yaitu kualitas semen, kesuburan ternak betina, keterampilan teknisi dan pengetahuan zootenik peternak (Toelihere, 2006). Menurut Widhyari, dkk (2015) Peningkatan kualitas dan kuantitas sperma merupakan salah satu solusi pemecahan masalah dalam rangka pengembangan peternakan nasional. Pemberian pakan yang memiliki zat gizi yang baik dan mampu meningkatkan kualitas sperma merupakan salah satu alternatif di dalam penyediaan bibit bermutu. Menurut Apriyanti (2017) Keberhasilan sistem perkawinan bisa dilihat dari keberhasilan perkawinan ternak yang dipengaruhi oleh kualitas semen yang dihasilkan. Evaluasi atau pemeriksaan semen merupakan suatu tindakan yang perlu dilakukan untuk melihat kuantitas dan kualitas semen. Pemeriksaan semen dibagi menjadi dua kelompok, yaitu pemeriksaan secara makroskopis dan mikroskopis. Pemeriksaan secara makroskopis meliputi volume, warna, bau, kekentalan, dan $\mathrm{pH}$ semen.

Antioksidan merupakan salah satu senyawa yang diperlukan oleh tubuh untuk menetralisir radikal bebas serta mencegah kerusakan yang ditimbulkan akibat radikal bebas. Antioksidan dapat melindungi spermatozoa dari kerusakan akibat radikal bebas. Antioksidan dapat meningkatkan kualitas sperma dengan menurunkan jumlah radikal bebas dalam tubuh yang dapat menyebabkan kerusakan pada membran sel. Buah Naga merupakan jenis buah yang kaya akan antioksidan. Hal menarik pada buah naga adalah manfaat dari kulit buahnya yang masih jarang dimanfaatkan. Hasil penelitian Noor, dkk (2016) menunjukkan ekstrak kulit buah naga merah memiliki kandungan antioksidan berupa vitamin $\mathrm{C}$, flavonoid, tanin, alkaloid, steroid, dan saponin berdasarkan hasil pengujian fotokimia dan FTIR. Antioksidan yang terkandung di dalam kulit buah naga merah diduga memiliki manfaat yang sangat luas. Pemberian ekstrak kulit buah naga merah diharapkan mampu meningkatkan kualitas semen ayam kampung melalui kandungan antioksidan yang terdapat di dalamnya, 
Oleh karena itu penelitian ini bertujuan untuk mengetahui pengaruh ekstrak kulit buah naga terhadap kualitas makroskopis semen ayam kampung.

\section{Metodologi}

\section{Materi}

Materi yang digunakan dalam penelitian ini adalah 12 ekor ayam Kampung jantan dengan kisaran umur 1-1,5 tahun, ekstrak kulit buah naga merah, pakan komersil, alkohol 70\%, pH meter, kertas label, kapas dan tisu. Alat pendukung yang digunakan adalah kandang ayam dan peralatannya, spoit, tabung eppendorf untuk menampung sperma, dan pipet tetes.

\section{Metode}

Penelitian ini merupakan penelitian eksperimental yang terdiri dari 4 perlakuan dan 3 ulangan. 12 ekor ayam Kampung jantan dibagi secara acak dalam 4 kelompok perlakuan. Sebelum perlakuan, seluruh ayam diadaptasikan selama 10 hari dan hanya diberi pakan komersil dan air minum. Setelah adaptasi, perlakuan dengan memberikan ekstrak kulit buah naga diberikan secara oral menggunakan spoit selama 8 minggu dengan volume pemberian ekstrak kulit buah naga yang berbeda yaitu terdiri dari :

$\mathrm{P} 0=$ Kontrol

$\mathrm{P} 1=$ Ekstrak kulit buah naga $1 \mathrm{ml}$

$\mathrm{P} 2=$ Ekstrak kulit buah naga $3 \mathrm{ml}$

P3= Ekstrak kulit buah naga $5 \mathrm{ml}$

Kemudian setelah pemeliharaan dan pemberian perlakuan selama 8 minggu, dilakukan penampungan semen dengan metode pengurutan. Sperma yang telah ditampung kemudian diuji kualitasnya di Laboratorium secara makroskopis.

\section{Parameter yang Diamati}

Pengamatan secara makroskopis meliputi :

- Warna semen : Melihat secara langsung warna semen yang telah ditampung. Semen yang normal berwarna putih keruh-putih susu.

- Bau semen : Semen yang telah ditampung didekatkan ke hidung untuk mencium baunya. Semen yang normal memiliki bau khas sperma.

- Konsistensi semen : Menggoyangkan semen yang ada di dalam tabung untuk mengetahui kental atau encer.

- Volume semen : Semen yang telah ditampung kemudian dimasukkan ke dalam tabung eppendorf dan kemudian membaca skala yang ada pada tabung.

- $\mathrm{pH}$ semen : Mengambil kertas indikator $\mathrm{pH}$ kemudian dicelupkan kedalam semen yang telah ditampung, warna kertas indikator yang berubah kemudian dicocokkan warnanya dengan pengukur yang tersedia.

\section{Analisa Data}

Data yang diperoleh dianalisis ragam berdasarkan Rancangan Acak Lengkap (RAL). Apabila menunjukkan perbedaan maka dilanjutkan dengan uji Duncan.

\section{Hasil}

Hasil evaluasi semen secara makroskopis meliputi warna, bau, konsistensi, volume, dan $\mathrm{pH}$ semen pada ayam kampung dengan

pemberian ekstrak kulit buah naga disajikan dalam Tabel 1.

Tabel 1. Rataan hasil evaluasi makroskopis semen ayam kampung

\begin{tabular}{ccccc}
\hline \multirow{2}{*}{ Parameter } & \multicolumn{4}{c}{ Perlakuan } \\
\cline { 2 - 5 } & P0 & P1 & P2 & P3 \\
\hline Warna & Putih susu & Putih Susu & Putih Susu & Putih Susu \\
Bau & Khas & Khas & Khas & Khas \\
Konsistensi & Kental & Kental & Kental & Kental \\
Volume (ml) & $0,43 \pm 0,06^{\mathrm{a}}$ & $0,50 \pm 0,10^{\mathrm{ab}}$ & $0,63 \pm 0,06^{\mathrm{b}}$ & $0,53 \pm 0,06^{\mathrm{ab}}$ \\
pH & $7,17 \pm 0,29^{\mathrm{a}}$ & $7,00 \pm 0,00^{\mathrm{a}}$ & $7,00 \pm 0,00^{\mathrm{a}}$ & $7,17 \pm 0,2^{\mathrm{a}}$ \\
\hline
\end{tabular}

Keterangan : Notasi yang berbeda menunjukkan pengaruh yang nyata $(\mathrm{p}<0,05)$

\section{Warna}

Warna semen dapat diamati secara langsung dari tabung penampung semen yang terbuat dari plastik tembus pandang. Warna semen umumnya merupakan indikator kepadatan konsentrasi spermatozoa dalam sekali ejakulasi (Putranto, dkk. 2020). Hasil pengamatan warna pada semen antara kontrol dan ayam yang diberi ekstrak kulit buah naga berdasarkan tabel 1 menunjukkan hasil yang sama yaitu berwarna putih susu. Ekstrak kulit buah naga yang diberikan tidak memberikan pengaruh terhadap warna semen yang dihasilkan. Hasil ini sama dengan hasil penelitian Hijriyanto, dkk (2017) pada ayam Bangkok warna semen yang diperoleh berwarna putih susu. Warna semen merupakan cerminan dari kekentalan semen. Dalam kondisi normal, semakin pekat warna semen yang terlihat, maka semakin kental konsistensi semen tersebut. Demikian juga sebaliknya pada semen yang berwarna agak pucat akan didapatkan konsistensi semen yang encer (Toelihere, 1985). Warna putih susu pada hasil penelitian ini dapat dikatakan normal karena tidak terkontaminasi dengan kotoran yang dapat menyebabkan perubahan pada warna semen hal ini sesuai dengan pendapat Arifiantini (2012) bahwa secara umum, warna semen adalah putih keruh, putih susu, krem, krem kekuningan, sampai warna putih keabu-abuan. Warna-warna yang disebutkan tersebut adalah normal. Menurut (Kartasudjana, 2001) semen ayam umunya berwarna putih seperti air susu. Warna kemerahan merupakan tanda bahwa semen terkontaminasi oleh darah 
segar, sedang apabila warnanya mendekati coklat dapat merupakan tanda bahwa darah yang mengkontaminasi semen sudah mengalami dekomposisi. Warna kehijauan merupakan tanda adanaya bakteri pembusuk.

\section{Bau}

Bau semen dapat dinilai dengan cara mengibaskan tangan di atas tabung penampung semen. Hasil pengamatan bau pada semen antara kontrol dan ayam yang diberi ekstrak kulit buah naga berdasarkan tabel 1 menunjukkan pemberian ekstrak kulit buah naga tidak memberikan pengaruh terhadap bau pada semen yang dihasilkan . Hasil yang diperoleh sama antara kontrol dan ayam yang diberi perlakuan yaitu memiliki bau khas sperma. Bau semen yang dihasilkan pada penelitian ini sama dengan hasil penelitian Zen, dkk (2020) rataan yang didapat pada bau semen ayam kampung tiap individu adalah bau khas spermin. Bau khas sperma pada semen yang ditampung menandakan bahwa kualitas semen baik dan normal, hal ini sesuai dengan pendapat (Kartasudjana, 2001) Semen yang normal, pada umumnya, memiliki bau amis khas disertai dengan bau dari hewan itu sendiri. Bau busuk bisa terjadi apabila semen mengandung nanah yang disebabkan oleh adanya infeksi organ atau saluran reproduksi hewan jantan. Hal ini juga didukung oleh pendapat Arifiantini (2012) bahwa bau semen yang normal adalah bau anyir atau bau amis. Bau yang menyengat sangat tidak diharapkan karena berhubungan dengan kandungan bakteri yang terkandung dalam semen tersebut.

\section{Konsistensi}

Konsistensi semen adalah derajat kekentalan semen dapat diperiksa dengan cara menggoyang tabung yang berisi semen. Konsistensi semen yang diperoleh dalam penelitian ini baik pada kontrol maupun ayam yang diberi ekstrak kulit buah naga memiliki konsistensi yang kental dan dapat dikatakan normal dan baik. Tabel 1 menunjukkan ekstrak kulit buah naga yang diberikan tidak berpengaruh terhadap konsistensi semen. Hasil yang diperoleh dalam penelitian ini sama dengan hasil penelitian Lubis, dkk (2012) yaitu konsistensi semen kental pada ayam kampung yang diberi Suplementasi ENERVON-C dan SANTA-e dalam Pakan. Menurut Putranto (2020) konsistensi semen dapat dilihat dengan memiringkan tabung penampung semen lalu menegakannya kembali. Bila jatuhnya semen lambat maka konsistensinya tinggi semen yang baik adalah dengan konsistensi tinggi atau kental. Menurut Khaeruddin, dkk (2020) Konsistensi semen yang kental menunjukkan tingginya konsentrasi spermatozoa. Menurut Evans dan Maxwell (1987) konsistensi semen tergantung pada konsentrasi spermatozoa dan seminal plasma, semen yang mengandung konsistensi kental lebih banyak mengandung spermatozoa dibanding dengan semen yang konsistensinya encer. Sehingga semakin kental konsistensi semen menandakan bahwa jumlah spermatozoanya tinggi. Menurut Garner dan Hafez (2000), Derajat kekentalan semen yang baik hampir sama atau lebih kental dari susu, sedangkan semen yang jelek warna dan kekentalannya sama dengan air buah kelapa.

\section{Volume}

Volume semen merupakan salah satu langkah awal untuk menilai produktifitas dari pejantan. Hasil pengamatan volume semen pada tabel 1 menunjukkan volume rata-rata semen ayam kampung $\mathrm{P} 0, \mathrm{P} 1, \mathrm{P} 2$, dan P3 berturut-turut $0,43 \mathrm{ml} ; 0,50 \mathrm{ml} ; 0,63 \mathrm{ml} ; 0,53 \mathrm{ml}$. Rataan volume semen ayam yang diberi perlakuan lebih tinggi dibandingkan dengan ayam yang tidak diberi perlakuan. Hasil analisis menunjukkan perbedaan yang nyata $(\mathrm{P}<0,05)$ antara ayam yang tidak diberi perlakuan (P0) dengan ayam yang diberi ekstrak kulit buah naga $3 \mathrm{ml}$ (P2). Hal ini menunjukkan bahwa pemberian ekstrak kulit buah naga diduga dapat mempengaruhi volume semen ayam kampung. Hasil penelitian ini sejalan dengan penelitian yang dilakukan oleh Mustafa, dkk (2017) bahwa pemberian kombinasi pakan fermentasi asal ampas tahu, jagung, dedak padi dan bungkil kedelai dengan multi enzim pencernaan dan vitamin E dalam ransum komersial selama 35 hari dapat meningkatkan volume semen ayam arab. Meningkatnya volume semen ayam arab setelah pemberian kombinasi pakan fermentasi asal ampas tahu, jagung, dedak padi dan bungkil kedelai dalam ransum komersial kemungkinan disebabkan peningkatan nilai nutrisi ransum. Selain itu juga terjadi keseimbangan zat-zat makanan dan saling melengkapi yang dibutuhkan oleh ayam arab sehingga dapat menunjang berlangsungnya proses spermatogenesis secara optimal. Kulit buah naga memiliki beberapa zat nutrisi yang baik termasuk vitamin $\mathrm{E}$ dan vitamin $\mathrm{C}$, hal ini kemungkinan mempengaruhi volume semen yang dihasilkan pada ayam yang diberi ekstrak kulit buah naga karena dapat menunjang berlangsungnya proses spermatogenesis secara optimal. Volume semen yang diperoleh dalam penelitian ini lebih tinggi dibandingkan dengan volume semen hasil penelitian Khaeruddin, dkk (2020) dengan pemberian minyak hati ikan kod pada ayam kampung, volume rata-rata semen yang dihasilkan adalah $0.31 \pm 0.02 \mathrm{ml}$. Volume semen yang diejakulasikan pada penelitian ini termasuk normal berdasarkan pendapat Toelihere (1993) bahwa volume semen ayam berkisar antara 0,3-1,5 ml per ejakulat. Menurut Evans dan Maxwell (1987) banyaknya volume semen yang dihasilkan per ejakulasi akan menentukan tingkat pengenceran untuk keperluan inseminasi buatan.

\section{pH}

Derajat keasaman semen diukur dengan $\mathrm{pH}$ meter. Derajat keasaman $(\mathrm{pH})$ semen sangat berpengaruh terhadap daya hidup spermatozoa. Hasil pengamatan $\mathrm{pH}$ semen pada tabel 1 menunjukkan $\mathrm{pH}$ rata-rata semen ayam kampung P0, P1, P2, dan P3 berkisar antara 7-7,17. Hasil analisis tidak menunjukkan perbedaan yang nyata $\quad(\mathrm{P}>0,05)$. Pemberian ekstrak kulit buah naga tidak berpengaruh terhadap $\mathrm{pH}$ semen yang dihasilkan. Namun, $\mathrm{pH}$ yang diperoleh termasuk normal hal ini sesuai dengan pendapat Toelihere (1981) bahwa $\mathrm{pH}$ sperma ayam berkisar antara 6,3 sampai 7,8 . Hasil pengamatan $\mathrm{pH}$ pada penelitian ini mendekati hasil yang diperoleh Kusumawati, dkk (2020) derajat keasaman $\mathrm{pH}$ pada ayam Kampung adalah 7,35 $\pm 0,52$ dan derajat keasaman $\mathrm{pH}$ pada ayam Arab adalah 7,2 $\pm 0,42$. Hasil pengamatan ini juga sama dengan hasil penelitian Wajo (2009) yaitu Rata-rata $\mathrm{pH}$ semen 
pada perlakuan $10 \%$ dan $20 \%$ ekstrak rumput kebar menunjukkan hasil 7- 7.5. Hal ini dapat terjadi karena umumnya semen ayam bersifat agak basa yaitu antara 7,0 7.6. Tinggi rendahnya nilai $\mathrm{pH}$ semen yang dihasilkan juga berkaitan dengan konsentrasi spermatozoa (Aisah, 2017). Konsentrasi spermatozoa yang tinggi menyebabkan semen lebih asam daripada semen dengan konsentrasi spermatozoa yang rendah (Bearden dan Fuquay, 1984). Menurut Toelihere (1981) derajat keasaman (pH) semen dipengaruhi oleh proses metabolisme spermatozoa yang berlangsung secara anaerobik. Proses metabolisme spermatozoa yang berlangsung sampai hasil akhir menghasilkan asam laktat.

\section{Kesimpulan}

Berdasarkan hasil penelitian, maka dapat disimpulkan bahwa pemberian ekstrak kulit buah naga tidak memberikan pengaruh yang nyata terhadap warna, bau, konsistensi, dan $\mathrm{pH}$ semen tetapi memberikan pengaruh pada volume semen yaitu volume semen ayam yang diberi perlakuan lebih tinggi dibandingkan dengan ayam yang tidak diberi perlakuan. Secara keseluruhan semen yang diperoleh memiliki kualitas yang baik dan normal baik yang diberi perlakuan maupun yang tidak diberi perlakuan.

\section{Ucapan Terima Kasih}

Ucapan Terima Kasih kepada Direktorat Riset dan Pengabdian Masyarakat Kementerian Riset dan Teknologi / Badan Riset dan Inovasi Nasional yang telah mendanai penelitian ini serta semua pihak yang telah ikut serta membantu jalannya penelitian ini.

\section{Daftar Pustaka}

Artikel jurnal:

Aisah, S., Isnaini, N., dan Wahyuningsih, S. 2017. Kualitas Semen Segar dan Recovery Rate Sapi Bali Pada Musim Yang Berbeda. Jurnal Ilmuilmu Peternakan Vol. 27 (1) : 63-79.

Apriyanti, D., Samsudewa, D., dan Ondho, Y. S. 2017. Perbedaan Kualitas Semen Segar Domba Batur dalam Flock Mating dan Pen Mating secara Mikroskopis. Jurnal Sain Peternakan Indonesia Vol. 12, No. 1.

Danang, D. R., Isnaini, N., dan Trisunuwati, P. 2012. Pengaruh lama simpan semen terhadap kualitas Spermatozoa ayam kampung dalam pengencer ringer's Pada suhu 40C. Jurnal Ternak Tropika Vol. 13, No.1: 47-57.

Hijriyanto, M., Dasrul., dan Thasmi, C. N. 2017. Pengaruh Frekuensi Penampungan Semen Terhadap Kualitas Spermatozoa Pada Ayam Bangkok. JIMVET. 01(1) : 046-053.

Kusumawati, E. D., Krinaningsih, A. T. N., dan Walangara, A. U. K. 2020. Kualitas Spermatozoa Ayam Kampung dan Ayam Arab dengan Lama Simpan yang Berbeda Pada Suhu Ruang. Jurnal Sains Peternakan, Vol. 8, No. 1, pp:41-56.

Lubis, T. M., Dasrul, Hamdan, Fauziah. 2012. Efek Suplementasi ENERVON-C dan SANTA-e dalam Pakan terhadap Motilitas Spermatozoa Ayam Kampung. Jurnal Agripet Vol. 12, No. 1.

Mustafa, Dasrul, Yaman, M. A., Wahyuni, S., dan Sabri, M. 2017. Pengaruh Pemberian Kombinasi Pakan Fermentasi dengan Multi Enzim dan Vitamin E dalam Ransum terhadap Peningkatan Kualitas Semen Ayam Arab. Agripet Vol 17, No. 1.

Noor, M. I., Yufita, E., dan Zulfalina. 2016. Identifikasi kandungan Ekstrak Kulit Buah Naga Merah Menggunakan Fourier Transform Infrared (FTIR) dan Fitokimia. Journal of Aceh Physics Society (JAcPS), Vol. 5, No.1, pp.14-16.

Putranto, H. D., Nurmeiliasari, Harferry, K. T. 2020. Studi Kualitas Semen Ayam Burgo. Buletin Peternakan Tropis, Vol 1(1):10-15.

Wajo, M. J., dan Jentewo, W. F. 2009. Pengaruh Pemberian Ekstrak "Rumput Kebar" (Biophytum petersianum klotzsch) Melalui Air
Minum Terhadap Kualitas Semen Ayam Buras. Jurnal Ilmu Peternakan, hal. 49-56.

Widhyari, S. D., Esfandiari, A., Wijaya, A., Wulansari, R., Widodo, S., dan Maylina, L. 2015. Tinjauan Penambahan Mineral Zn dalam Pakan Terhadap Kualitas Spermatozoa pada Sapi Frisian Holstein Jantan. Jurnal Ilmu Pertanian Indonesia (JIPI) Vol. 20 (1) : 72-77.

Zen, A. A., Ondho, Y. S., Sutiyono. 2020. Seleksi Pejantan Ayam Kampung Berdasarkan Breeding Value Terhadap Gerak Massa, Abnormalitas dan Motilitas Spermatozoa. Jurnal Sain Peternakan Indonesia, Volume 15 (3).

Buku :

Arifiantini, R. I. 2012. Teknik Koleksi dan Evaluasi Semen Pada Hewan. IPB Press, Bogor.

Bearden, H. J., and Fuquay, J. W. 1984. Applied Animal Reproduction. 2nd Edition. Reston Publishing Company, Inc : Virginia.

Evans, G.W., and Maxwell, M.C. 1987. Salamons Artificial Insemination Of Sheep and Goats. Butterworths. London.

Garner, D.L., and Hafez, E.S.E. 2000. Spermatozoa and Seminal Plasma In Reproduction in Farm Animal. 7th ed., E.S.E. Hafez (ed). Lea and Febiger Publishing, Philadelphia.

Kartasudjana, R. 2001. Teknik Inseminasi Buatan Pada Ternak. Modul Program Keahlian Budidaya Ternak. Departemen Pendidikan Nasional. Proyek Pengembangan Sistem dan Standar Pengelolaan SMK. Direktorat Pendidikan Menengah Kejuruan. Jakarta.

Toelihere, M. R. 1981. Inseminasi Buatan pada Ternak. Cetakan ke-VI. Angkasa. Bandung.

Toelihere, M.R. 1985. Inseminasi Buatan Pada Ternak. Angkasa. Bandung.

Toelihere, MR. 2006. Inseminasi Buatan pada Sapi. Penerbit Angkasa Bandung.

Yaman, A. 2013. Ayam Kampung Pedaging Unggul. Penebar Swadaya, Jakarta. 